\title{
The Birth of a New Party: Podemos, a Hurricane in the Spanish Crisis of Trust
}

\author{
Jose M. Pavía1, Anselm Bodoque², Joaquín Martín² \\ ${ }^{1}$ GIPEyOP, Department of Applied Economics, Universitat de Valencia, Valencia, Spain \\ ${ }^{2}$ GIPEyOP, Department of Constitutional Law, Political and Administrative Sciences, Universitat de Valencia, Valencia, Spain \\ Email: pavia@uv.es, Anselm.Bodoque@uv.es, Joaquin.Martin@uv.es
}

How to cite this paper: Pavía, J.M., Bodoque, A. and Martín, J. (2016) The Birth of a New Party: Podemos, a Hurricane in the Spanish Crisis of Trust. Open Journal of Social Sciences, 4, 67-86.

http://dx.doi.org/10.4236/jss.2016.49008

Received: August 19, 2016

Accepted: September 18, 2016

Published: September 21, 2016

Copyright $\odot 2016$ by authors and Scientific Research Publishing Inc. This work is licensed under the Creative Commons Attribution International License (CC BY 4.0).

http://creativecommons.org/licenses/by/4.0/

\begin{abstract}
A significant number of European electors are turning their backs on traditional mainstream parties. European party systems are being challenged by an increasing number of (new) radical parties, which defied the Christian-social democrat alternation that has dominated Western European countries for decades. In Spain, a political earthquake started after the 2014 European Parliament election. In the context of the worst global economic crisis in the last 80 years (which in Spain is also a social, political and institutional crisis), a party called Podemos won $7.9 \%$ of votes and five MEPs, significantly altering the traditional balance of the Spanish party system. This paper studies the causes of the support received by Podemos on 2014 EP elections, dissects its political strategy and analyses the characteristics of the electorate that made possible the birth of this new party. The analysis, which is illustrated using micro-data of twelve surveys, discloses Podemos political agenda.
\end{abstract}

\section{Keywords}

Political Strategy, Cleavage Change, Post-Marxism, Populism, EP Elections, Democracy Satisfaction

\section{Introduction: The Momentum of the Hurricane}

A hurricane is known for its devastating effects but it can also bring some benefits, such as a drought ends. The emergence of Podemos ("We can", in English) could be described in the same way. On one hand, Podemos has had devastating effects on the stability of the Spanish party system, suddenly becoming in a position to challenge PP (the Conservative Party) and PSOE (the Socialist Party), which have dominated the Spanish electoral scene in recent decades. Indeed, at the time of reviewing this paper, the Spanish party system has been showing an unknown level of fragmentation and an inability 
to come to an agreement to form a new government. This has led to repeat, in just six months, the 2015 General election and the event of a third election is ultimately feasible. On the other hand, the emergence of Podemos has generated a new and innovative dynamic in the Spanish political arena (forcing big parties to respond to the grave problems presented not only by the economy but also by the political and institutional system) and also has resulted in more plural regional and national parliaments.

Both phenomena, a hurricane and Podemos, cannot only be compared for their effects but also for their dynamics. A hurricane starts quietly but develops quickly gaining in strength over large areas of warm water, diminishing as it spreads across land. Similarly, after the wave of social outrage that heated the political climate in Spain in 2011 [1], support for this new political force rapidly gained momentum within those electorates who no longer identified themselves with the traditional political parties, blaming them for the state of the country. The growth of support, however, slowed down once reaching more loyal electorate areas. On occasions, nevertheless, hurricanes can travel hundreds of kilometres inland causing severe flooding and, what's more, their positive feedback loop of air currents continue growing whilst the conditions are favourable for their development.

The aim of this research is not to predict the future trajectory of hurricane Podemos. This paper just analyses Podemos first year of live. The goals of this research are to analyze, from a neutral, scientific and external position, the reasons for the Podemos phenomenon, to discern the strategy followed by its leaders to capitalise on the circumstances, and to identify where its initial votes comes from and what the ideological and socio-demographic profile is of the citizens that made possible the irruption of this new party.

Section 2 offers some details about Podemos birth and its meteoric evolution. Section 3 shows a profile of the situation in Spain when Podemos was born. Section 4 explores the keys of Podemos success and goes deep by dissecting its political strategy. Section 5 focuses on studying the characteristics of Podemos supporters and from where their supports come from. Section 6 concludes.

\section{The Birth of Podemos}

Podemos was born as a political force on 14 January, 2014, when a group of academics, journalists and social activists published a manifesto with the objective of "converting the indignation into political change" by developing a political platform capable of presenting a candidacy at the European Parliamentary elections four months later. On 11 March, the group was registered as a political party and by 21 April Podemos had collected the required support to present their candidacy: 15,000 electoral signatures. In only four months, Podemos had become the fourth most voted Spanish party, with 7.9\% of the votes, which resulted in five European Parliament seats (MPEs). Pablo Iglesias $^{1}$, leader of Podemos, was presented shortly after as candidate of European United Left to be President of the European Parliament.

${ }^{1}$ Section 4, and mainly subsection 4.4.4, offers details of the figure of the Podemos main leader Pablo Iglesias. 
From that moment, and with the objective of winning the next general elections, the group started a process of institutionalization as a party, celebrating its Asamblea Ciudadana the weekend of 18-19 October, 2014 and starting to elect representatives for its new regional and local organizational structure. The political proposition of Podemos was based on an encouragement of social policies, a reinforcement of the fight against political corruption and an increase of direct democracy. Amid this process, CIS barometer [2] stood Podemos as the third most powerful political force, with levels of support similar to PP and PSOE. Forecasts from all polls placed Podemos as one of the three main parties of Spain (see Figure 1).

In less than a year, a political formation that appeared from nowhere has become a credible political alternative to confront the two traditional major parties of the Spanish political panorama and has achieved it by changing the scene of the political competition. The electoral choice set out by Podemos asks the voter to choose not between Left and Right but between the people (Podemos) and la casta (PP and PSOE), the latter being blamed for the critical situation in which Spain found itself.

This new discursive strategy of Podemos is what has led many political analysts to compare it to Populism, a feature seen in many of the new parties that have emerged across Europe during the last few years in reaction to the economic, social, political and institutional crises Europe is living. These populist parties, despite the differences between them and the difficulties the concept entails, have won as a whole almost a quarter of MEPs: Syriza in Greece, MoVimento 5 Stelle in Italy, Alternative für Deutschland in Germany, Sverigedemokraterna in Sweden, National Front in France or UKIP in the United Kingdom, to which we can add Podemos in Spain. From Left, Podemos performs a radical criticism of the Spanish party system, the way the political system works, the European process of decision-making, the austerity policies and the management of debt. Its scope is Spanish, but its impact is European. The emergence and

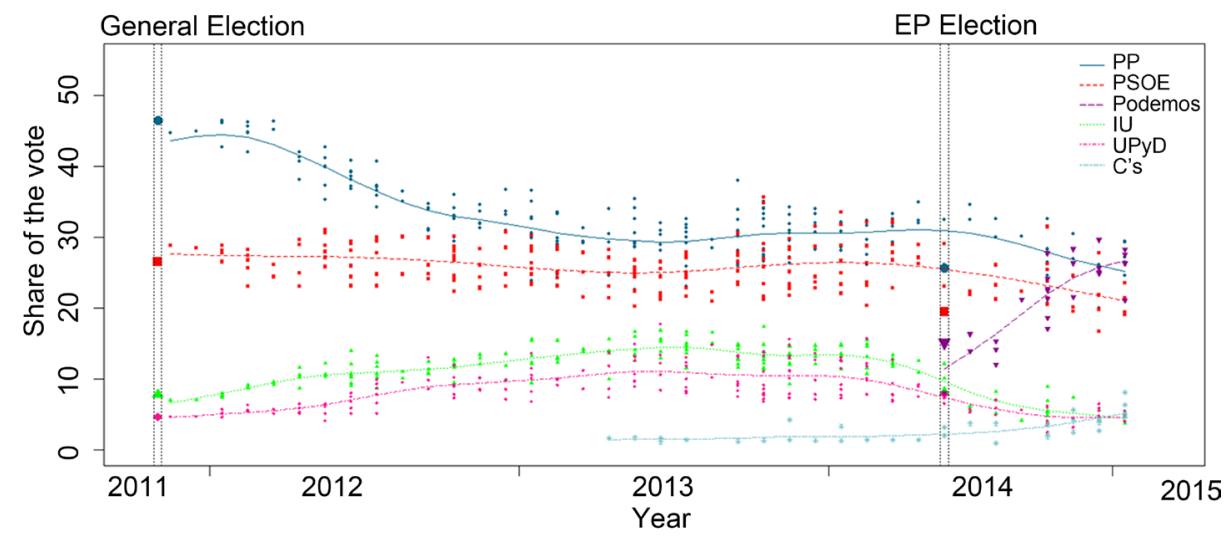

Figure 1. Evolution of vote shares for General Elections according to opinion polls during the Tenth Spanish Legislature. Own elaboration from 191 polls published in mass media from December, 2011 to January, 2015 (just a year after Podemos birth). On $20^{\text {th }}$ November, 2011: General Election. On $25^{\text {th }}$ May, 2014: European Parliament Election. Smoothing splines used to polling the polls. Only national parties shown: PP (deep blue), - PSOE (red), $\nabla$ Podemos (purple), $\triangle$ IU (green), UPyD (pink) and ** C’s (sky blue). 
growth of Podemos must be explained within the questioning wave of traditional politics that is striking Europe, with the case of Syriza in Greece as the most striking example [3].

\section{The Political Situation in Spain at the Beginning of 2014}

In this research, we inquire into the reasons why a phenomenon such as Podemos has occurred, a situation rarely seen within party systems. For more than three decades the two biggest Spanish parties, PP and PSOE, have secured between them an electoral support of around $80 \%$ of votes, and so has been until January 2014, when Podemos appeared. What was the political situation of Spain at that time?

After almost three decades of uninterrupted growth and prosperity, in 2008 Spain was hammered, equally to other European countries, by a striking economic crisis: increase in unemployment, cuts in public services, poverty growth and other related blights. The economic crisis became associated with an institutional crisis. Citizens now not only mistrusted Government and Opposition but they mistrusted the whole political system. The constitutional framework that had stood in Spain for three long decades was suddenly losing its lustre for citizens. In little time, they realised that the country was being "governed" by foreign ministries in other countries; that the monarchy was not what it seemed; that judicial power was biased; that the great political parties were rife with corruption; that judges who pursued corrupt politicians and their allies were side-lined in their careers, whilst the sentences given to the convicted were never served; that Catalonia wanted independence; that the black economy accounted for a quarter of GDP; that administration and public services were rapidly deteriorating. To sum up, Crown, Parliament, Judiciary, Constitutional Court, the territorial organization of the country, small businesses, the welfare state; all under question within the economic crisis.

To demonstrate the cataclysm that occurred in a political and social system that, until then, had been highly valued by its citizens, we can compare the responses to questions about institutions carried out by CIS in 1998 ([4]-[6]) with those performed in 2012 and 2013 ([7]-[9]). In Figure 2, which shows the value given by Spaniards to institutions and institutional frameworks in 1998 and fifteen years later, one can see the enormous deterioration that these institutions have suffered. The average Spaniard stated a growing disaffection with its key institutions. Citizens tend to be clearly dissatisfied with how democracy works because they do not perceive elites sharing their concerns and feel that these are neither attentive nor responsive to society needs [10].

If the crisis of confidence in the Spanish political system and its institutions was already apparent in 2012, the January 2014 CIS barometer [11] did little more than to confirm it. After six years of crisis, people's perceptions had begun to settle in their consciousness. The economic situation was seen as bad or very bad by $86.7 \%$ of population. The political situation was perceived as bad or very bad by $81.8 \%$. And, what's worse, the same percentage believed that the situation would be the same or even worse within a year. Corruption and fraud, and politicians, parties and politics were cited as 

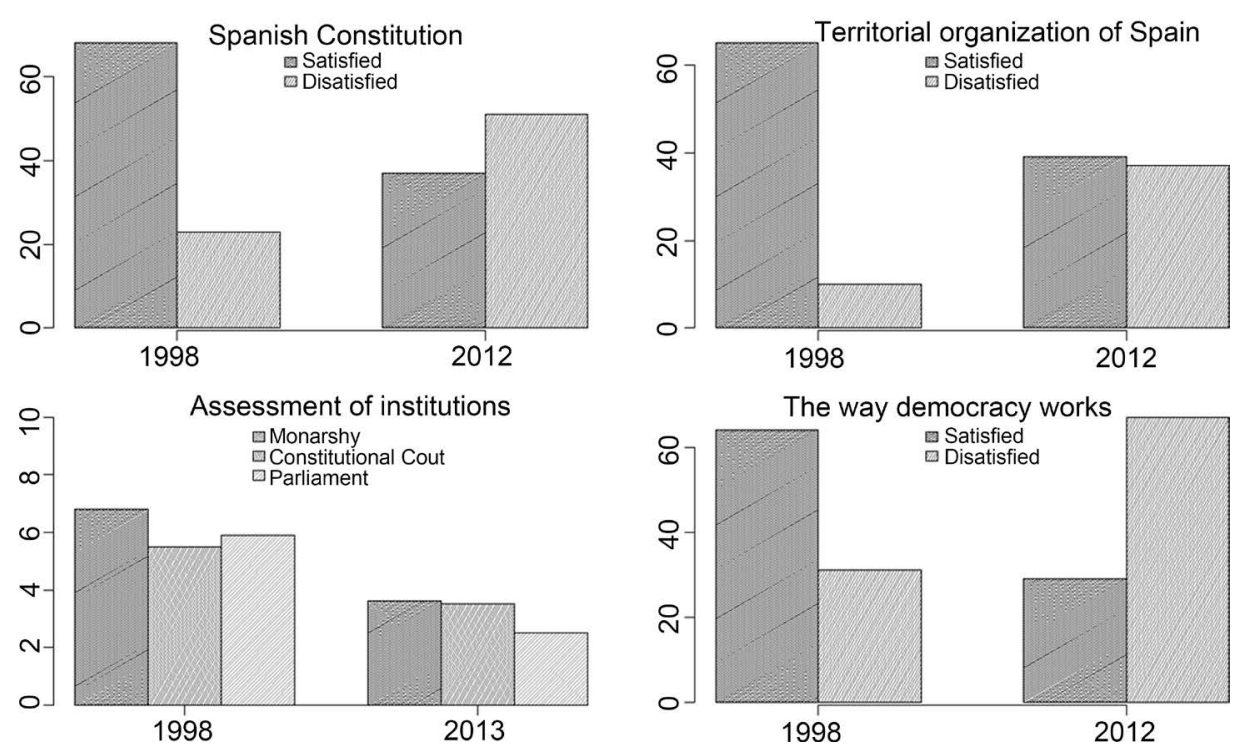

Figure 2. Evaluation and satisfaction with institutions of Spaniards before Podemos born compared to 1998. In top-left, top-right and bottom-right panels the percentage of people very satisfied and satisfied is compared for several issues against the percentage of people very unsatisfied and unsatisfied. In bottom-left panel, average values of trust in institutions are displayed (null trust 0, maximum trust 10). Own elaboration from CIS ([4]-[9]).

two of the main problems in Spain. Government management (PP) and opposition actions were disapproved of by $70.8 \%$. In this context, it is not surprising that the CIS election forecast for the two great parties did not reach 60\% $32.1 \%$ PP and $26.6 \%$ PSOE). However, no other political force was capitalising on this situation, other than small increases in support for IU and UPyD. Spaniards wanted to vote but did not know who to vote for.

The need for an alternative, fresh political approach had been germinated three years earlier when, on 15 May 2011, thousands of citizens, the majority of them young adults, occupied for days the main emblematic squares of more than 50 Spanish cities [1]. This rebellious social movement sought to express the outrage of Spanish citizens, but at the time did not build a clear and articulated political stance. According to [12], the mobilization was a noise that instead of alerting baffled most politicians, who talked down its significance despite the striking $36 \%$ of Spaniards expressing their wish the $15-\mathrm{M}$ movement became a party to revive democracy. However, as [13] said "politics is not used to having a vacuum. If institutions and political parties are not capable of adequately articulating or conveying the ever-emerging ideas, interests, projects or demands of the people, then new voices, people or movements will appear to express these genuine needs" and one of them has been Podemos. As its leader stated " $\mathrm{t}] \mathrm{he}$ emergence of our political force, PODEMOS, can only be understood in this context" ([14], p. 146).

\section{The Roots of Podemos Success}

The situation, as we have shown, was ripe for a political figure to occupy this space. The 
candidates were various. For the previous five years the best candidate seemed to be UPyD. Other candidates also appeared, such as C's that in 2014 was in the process of making the jump into national politics, and other more recently created parties, such as VOX. However, in 2014 none of them has been born to the Spanish political scene in the same way as Podemos ${ }^{2}$. Probably the reason of the differential success of Podemos is that these were formations that have played with the traditional weapons of the political party competition. They were not seen as something new or sufficiently different for former PP and PSOE supporters to switch allegiance. The question is, therefore, what it is about the phenomenon Podemos that could explain the change in electoral behaviour of a large proportion of the Spanish voters.

\subsection{The Origin of Podemos. A Common Experience}

The leaders of Podemos are young, but neither naive nor newcomers to politics. Pablo Iglesias himself was in Juventudes Comunistas and later in very active political and social groups; whilst Juan Carlos Monedero, Podemos former number three, was a member of IU between 1986 and 2005, becoming the right-hand man of IU leader. Likewise, all of them participated in, in one way or another, the "indignation" demonstrations that took place in Spain from 15 May 2011 onwards. However, what marks them out, as a single and cohesive group, are two further things in common: they were all active in the Centro de Estudios Políticos y Sociales (CEPS), and members of the Universidad Complutense de Madrid ([15], p. 22).

In the early part of 2000, a small group of faculty members of political science at the Universidad Complutense de Madrid (UCM) became aware of the importance of discourse in defining the actual conflicts in society. Changing the discourse would change our perception of reality and, from there new alternatives for the future could be built. This group connected with CEPS, a previous initiative from the 90's active at the Universitat de Valencia, specialized in the Latin-American constituent processes. This association, latterly Foundation, aligned them with the main political leaders of the so-called Socialism of the 21st century. The leaders of Podemos, as members of CEPS, participated in the constituent processes of Venezuela, Bolivia and Ecuador and also collaborated with emerging political forces and institutions in Peru, Guatemala, El Salvador, Colombia, Chile, Argentina and Paraguay.

Over several years, this group not only theorised over politics following the ideology of Ernesto Laclau (see next subsection), but they also collaborated with governments of some Latin-American countries through CEPS foundation. This common experience, universitary and Latin-American, was cohesive enough to create a group capable of drafting new political initiatives in a country in crisis and to do so with new tactics, both in theoretical and practical terms.

\subsection{A New Analysis of Reality. A New Discourse}

The leaders of Podemos have shaped their view of politics in the context of post-Marxism ${ }^{2} \mathrm{~A}$ year later C's followed Podemos track, claiming being a more reliable alternative but fishing mainly among former PP supporters. 
and, more specifically, in the context of post-structuralism. The post-structuralism "is a theoretical approach to knowledge and society that embraces the ultimate un-decidability of meaning, the constitutive power of discourse, and the political effectivity of theory and research" ([16], p. 95). Post-structuralism interprets economic rationalities as social constructs, taking various historical forms, specific regional ways of development and clearly defined geographies [17]. Identifying criticisms of the dominant knowledge provides the ability to challenge such concepts and develop alternative constructs.

In this sense, perhaps the most influential philosopher of the group is Ernesto Laclau [15], the leader of the so-called "Essex School of discourse analyses", who along with Chantal Mouffe wrote Hegemony and Socialist strategy [18], which many recognise as a foundational work of post-Marxism. The book attempts to overcome the limitations of economic Marxist determinism and of class struggle as the only factors in social unrest. Society is divided and pluralist hostilities are generated within it. This is the reason why one cannot talk of a universal class or even a workers' identity. According to Laclau and Mouffle ([18], p. 84), “a fragmentation of positions' exists within the social agents themselves, and that these therefore lack an ultimate rational identity". A society without hostilities seemed impossible and Laclau and Mouffle tried to unite in a new process of identification, but on other foundations, the working class and the new social movements.

For Laclau, "without 'utopia', without the possibility of negating an order beyond the point that we are able to threaten it, there is no possibility at all of the constitution of a radical imaginary -whether democratic or of any other type". ([18], p. 190). Laclau defines politics as the fight for hegemony through conquering what he called "floating signifiers", which express the diverse social demands as hostile pluralism in which all the discrepancies can be stated and where the most important thing is the process and the call to action. The hidden side of this new hegemony is the loss of a clearly defined project.

The last part of Laclau's approach comes from the necessity to have a leader that expresses the hegemony as a cohesive identity. According to Laclau [19], when the popular masses previously excluded are incorporated into the political arena, new, less orthodox forms of leadership emerge from the liberal democratic point of view, such as Populism which, far from being an obstacle, guarantees democracy. For Laclau, Populism represents the essence of politics, that is, the creation of "We"; "We" that, following Carl Smith, can only be made antagonistically. It requires the construction of a global political subject that brings together the plurality of social demands. According to Laclau [20], this "We" needs a leader to represent it, "[i]n any process of representation there is always going to exist a double movement. One from the represented towards the representatives and another from the representative towards the represented. In this process, the identity of the latter is complemented and reconstructed by way of representation".

This revolutionary process has in Laclau's agenda a critical moment when institutions are unable to respond and they systematically block social demands, i.e., when a 
global crisis of trust occurs. When citizens are dissatisfied with the functioning of democracy it is the time of the populism break. The time for a new dichotomous division of society, but on new foundations that are not Marxist but populist: the people against the elites, the poor against the rich, the radical democracy against the ill and deciduous liberal democracy ([21], p. 155).

The application in discursive terms of this theoretical scheme to the Spanish reality by Podemos has been well summarised by [22]: "The first success of Podemos was to give the enemy a name: la casta... Once the contrary was named...all that was needed was that a group of... good communicators, experts in the use of the Internet... would build a... reconstruction of the world as a series of dichotomies: people versus the cast, (...) new politics versus old politics, common sense versus ideology, room for decisions versus party logic, the real country versus a country of elites, democracy versus oligarchy and the social majority versus the privileged minority".

Examples of this dichotomous reconstruction of the world in terms of the struggle of the people against la casta were numerous in Podemos discourse. An example of but a few quotes from its discourses are: "The left and the right parties of the regime seem very similar. Their sources, their appearance, their language, even their kind of politics are similar and, more important than the differences between them, is the difference that separates them from the average person"; "Europe is governed by absolutists and we will be their sans-culottes"; "The fight is between democratic possibilities or oligarchic closure"; "The problem is that if those who govern are the stewards of economic powers and not messengers for the citizens then things become complicated"; "If people do not get involved in politics, then others will"; "Podemos is the instrument of the underdog to beat the regime".

\subsection{A New Strategy. Replacing the Cleavage}

As Podemos said in its foundation political communication of October 2014, "the 15-M movement, along with the demonstrations that began, helped to articulate part of the dissatisfactions that had been, until then, ignored and depoliticized... One of the challenges for those representing Podemos was to articulate this unrest and its source" [23]. For this, they relied on their ability to think in strategic terms: "Not only we are good people with good ideas, we are also strategists and we are here to win" (Pablo Iglesias in an interview on TV). What they were also clear about, and what they themselves have stated in their political paper, is that the context of the present economic crisis had opened "a window of opportunity" to seize power ([15], p. 27) that required to act quickly before the PP use the economic recuperation as a tool and the PSOE fill "the vacant space: the moment is now".

Until the European elections in May the strategy of Podemos was to win as a complete alternative, deprecating the parties of la casta and using a fundamentally critical discourse, with little concrete details. Podemos had centred its strategy of denouncing la casta as being corrupt and incapable of solving the problems of Spain, refusing to be drawn into any other debate-such as abortion or territorial organization-that might 
distract voters from its priority: that the fight is not that between Left and Right but between the people (Podemos) and la casta (the traditional parties, especially PP and PSOE but also IU or the nationalists CiU and PNV). Podemos focused on replacing the main cleavages of Spanish politics (Left vs. Right, Centre vs. Periphery) with a new cleavage: we (the people) against they (the elite, including politicians). According to Errejón ([24], p. 29), "the issue is not that two sides preexist, i.e., subjects faced, and then the discourse that justifies them. The discourse is an activity that not only shows but creates, creates meaning, and is therefore a pre-formative activity. (...) The sides, the dispute between us and the others (those who are left out) are forged in the exercise of hegemonic relations".

The crisis in the model of representation and of the political parties had slowly but consistently weakened the electoral grounds of all the parties and their root identities ${ }^{3}$. Twenty years ago, being seen to be vulnerable to electoral situations could have been interpreted in many social spaces as a sign of insolvency or of political sophistication. Today that perception has changed. In many areas, the stigma has reversed and the faithful voters are who have to explain their electoral behaviour, who are seen in their environment as being manipulated, ill-informed or lacking in political education. So, the campaign discourse of Podemos was totally surprising and new. It attacked the big traditional parties where they least expected. As advocated by Ignatieff [27], in their strong points. Podemos attacked PSOE on the social front and PP on its patriotic front. Podemos criticised PSOE for having abandoned the discourse of wealth redistribution and accused PP of relinquishing power to the Troika (European Commission, European Central Bank and International Monetary fund), a body not elected by Spaniards [28].

\subsection{Bridges to Society: Circles, Social Networks, Media and a New Leadership}

Going public through a manifesto at the beginning of 2014, with limited financial means and without an organic structure as support, Podemos had to face national elections in just four months, being unknown to the public, against some competitors that had all these means and, furthermore, were well known. This is what is so surprising about the phenomenon Podemos. how could it obtain more than a million votes, almost $8 \%$ of cast votes? The answer had to be sought, beyond a capable, cohesive group with political experience and with a discourse and a defined and relevant strategy, in the bridges they built to win the confidence of a large part of voters: "Some carry out politics by putting up walls, we do it by building bridges". These bridges, in our opinion, are fourfold: discussion groups, social networks, mass media and a charismatic leader.

\subsubsection{Circles (Discussion Groups)}

The circles are discussion groups of people who regularly meet, face to face, to debate ${ }^{3}$ Election after election, the level of identification with the parties was less and the proportion of voters deciding their vote at the last minute increased. In 1996 General election barely $9 \%$ of voters declared to have reached a decision during the campaign [25]. In 2011 this proportion had almost tripled: $24 \%$ of voters reported having decided their vote during the campaign, with $11 \%$ in the last week and even $6 \%$ on Election Day [26]. 
and come up with solutions and actions to common problems. They are groups which usually have local roots-from city suburbs, towns or villages-and function as units or workgroups. They answer to the philosophy of participative democracy (about which authors such as MacPherson or Poulantzas theorised in the 70's and 80's), having evolved with the new century and anti-globalisation movements. In fact, they reflect the assembly spirit of 15-M [1]: decisions are taken unanimously, there are no elected officials, and spokespersons take turns in order to avoid egoism or any deviation from representative democracy. According to Laclau, the spirit of true democracy is that which directly responds to desires and wishes of people.

This structure worked through the EP campaign and was a motivational element for Podemos activists during the party foundation. Indeed, Podemos logo is made up with several circles. However, although this structure has continued, after October 2014 they have given way to a new organic structure with an elected team and an electoral system on the internet.

\subsubsection{Social Networks}

The electoral campaign on the social networks started to gain importance after Obama's triumph in 2008 [29]. Campaigning in social networks had more impact than circles and it required few resources, just access to the internet, a mobile phone or a computer, and the knowledge to succeed in the digital world. These are no special requirements for Podemos members and cadres. They are people with a lot of experience in the use of digital tools for political intervention and social mobilisation, even before 15-M movement. For example, the famous "flash mob" [30], which follows 11-M Madrid Islamic terrorist attacks and calls for demonstrations the day before 2004 Spanish General Elections, was initiated (as Pablo Iglesias revealed on a television interview) by people close to Podemos committee. In fact, as Ana Aldea, Redlines consultant, states "the preparation behind Podemos was very good and there was no need to train their activists to use social networks because they were already active in them. So, no need for slogans like in big parties, they moved on the internet in a natural way". [31].

With a group of between 15 and 20 volunteers organised in shifts from 10.00 to 23.00 hrs, the effort reaped results. Indeed, according to November 2014 figures [32], Podemos was the political group with the most support shown on networks $(428,000$ followers on Twitter, against 81,000 for PSOE and 177,000 for PP; and 856,000 in Facebook, way ahead of PP 77,000 and PSOE 73,000). In comparing leaders, Pablo Iglesias led with 663,000 followers on Twitter against 614,000 for Rajoy (PP) and 96,000 for Pedro Sánchez (PSOE). To this, it should be added the tens of regional and sector accounts promoted from Podemos circles and assemblies in Spain and the rest of the world.

\subsubsection{Mass Media}

Apart from circles and social networks, without doubt the most contributing factor to the electoral success of Podemos was the constant presence of its leader in mass media, with positive results in terms of image and delivery of a clear and strong message. In 
particular, from his appearances on the fourth and fifth most watched national television channels, La Sexta and Cuatro.

Pablo Iglesias and his team considered their media presence as a strategic question, for which they had been preparing for years. As stated by Pablo Iglesias himself: "We practise in political communication using the main arena of political socialisation, that of television". They were very involved in production programmes which were promulgated on the internet or on minor channels such as Canal $\mathrm{K}$ and Canal 33. It was these programmes, initially with low viewing audiences, where Pablo Iglesias grew as a presenter, interviewer or simply debater. His objective was twofold: to dominate the television media and to develop new formulas of political communication. After years of experimenting, the path followed bore fruit. The big television channels supported Pablo Iglesias, and occasionally other Podemos leaders, to bring something new to their political debates and, above all, a discourse that was completely different and provocative.

\subsubsection{A New Leadership}

The fourth bridge to society is marked out by the figure of the leader. A figure that, according to Laclau, has to represent the new political subject: the people. The Podemos leadership fell to a young university academic called Pablo Iglesias. His biography fitted in well with the new discourse and planned strategy ([33], pp. 31-33). Firstly, the name of Pablo Iglesias is not a neutral issue. Pablo Iglesias's parents, both socialists, decided to name him in honour of PSOE founder in 1879, who shared the same name and surname. The connotations of this name, therefore, connect with the mythical figure of traditional socialism, helping to implant the idea of recovery of the essence of socialism against its currently liberal derivation. Secondly, the leadership is associated with ability and expertise. Iglesias, aged 35, has a doctorate in political science and a law degree from UCM, where he was a lecturer from 2008 until he took on his role as MEP in July 2014. Thirdly, Iglesias has proven experience in political and social activism, both in Spain and abroad. Not only he was actively involved in Juventudes Comunistas for 14 years, but also, later during his university studies, he had an active presence in a number of different social movements mostly linked to anti-globalisation activities. Fourthly, he has a striking image. His goatee and ponytail are reminders of mythical revolutionary movements in other times: from Christ to Che Guevara. A revolutionary image that he himself likes to embrace ("the sky is not taken by consensus but by assault") and that has made him famous through his media presence. It is not surprising that Podemos decided strategically to use Pablo Iglesias's image to promote its EP campaign and that this appeared on the EP ballot paper instead of the party logo. Lastly, he is a good communicator. His training and experience in the media enabled him to come out unscathed from the interviews and debates he participates in.

\section{Who Votes Podemos}

The European Parliamentary election of May 2014 was the first electoral process in which Podemos participated. In it, Podemos obtained 1,253,837 votes and five seats of 
the 54 Spanish MEPs. This result was both a surprise and an unprecedented electoral success, although just a year after its born this seemed quite poor considering the expectations of electoral growth that polls showed for then (see Figure 1) and, moreover, after seeming its results in recent regional and national elections.

Recall vote is an important indicator in electoral behaviour analysis and one of the basic ingredients for bias correction of Spanish polls [34]. When voters in an electoral survey are inquired what they just voted for (in an exit poll) or what they had voted for, some days previously or even four years ago, the aggregate results practically never coincide with the actual election outcomes. This mismatch is not related to sampling error, neither to the quality of fieldwork nor to measurement errors [35]. The mismatch between actual and poll outcomes is mainly related to nonresponse bias (although, sometimes, it is also related to the difference between what people do and what they would have liked to have done). In election polls, nonresponse bias appears as a consequence of differences in the probability of supporters of various parties to either provide an answer of their vote or to partake in the survey, so the discrepancy represents an excellent indicator of the social stigma attached to each party, i.e., what the majority believe is viewed as right or wrong.

The differences between aggregated recall votes and actual voting result tends to favour winning candidates due to bandwagon and spiral of silent effects [36], with clear underestimations of losing candidates. The results of the post-electoral survey of CIS [37], carried out only a few days after EP elections, showed that recall vote for Podemos achieved the highest positive difference by far: $8 \%$ of the census recorded as having voted for Podemos (compared to $3.4 \%$ in reality). This result points to Podemos as the biggest winner in the election from a public opinion perspective.

Usually, however, the differences are generally not so large qualitatively. Probably, on this occasion, the higher recall vote towards Podemos might indicate the sympathy of a large number of voters who, not having voted for Podemos, might have done it if they had known how successful the candidature was going to be in elections $s^{4}$. Having made this assumption, it is highly unlikely that the socio-demographic profile of this group would have differed significantly from those that actually voted Podemos, so, as is normal when only nonresponse bias is present the distributions that we obtain conditioning on recall vote are a true reflection of reality. Next, using the microdata of the 2014 EP post-electoral survey conducted by CIS [37], we study the features of Podemos voters and compare them to its main competitors. Firstly, we will focus on their political-ideological characteristics then analyze their socio-demographic profile.

${ }^{4}$ Indeed, the analysis of the question about a hypothetical change of vote of the 2014 EP post-electoral survey [37] points on that line. This had not happened in the previous two occasions when this question was stated ([38] and [8]). In the 2004 General election post-election survey, after 11-M attacks [39], the question took on a particularly relevant sense. Similarly, the PP landscape victory of 2011 also endowed particular meaning to this question. Paradoxically, both in 2004 and in 2011 between $96 \%$ and $98 \%$ of main formations (PP, PSOE and IU) voters declared that they would have kept their vote should have known the results ([38] and [8]). However, after the 2014 EP elections, only Podemos (98\%) and PP (96\%) electorates expressed equivalent rates of loyalty. PSOE and IU voters showed significantly lower loyalty rates. 


\subsection{Political-Ideological Features}

The first question is where did the votes for Podemos come from? In other words, from what party had the voters defected? Table S1 (supplemental material) shows an estimate of the transfer of votes that occurred between the General elections of November 2011 and the European elections of May 2014. The by-column and by-row relative marginal distributions of Table S1 offer, respectively, an estimate of the composition of the votes of each party and an estimate of the proportion of voters of each option transferring their vote to each party. Figure 3 shows those numbers for the case of Podemos. The source of the votes to Podemos came mainly from PSOE (26.4\%) and, thereafter, from abstainers (19.8\%). In terms of electoral behaviour, the latter is one of the most complicated transitions. Podemos also attracted in a much greater proportion than either PP or PSOE new voters; those who turned 18 years old in the period between 2011 and 2014. However, the parties that showed the biggest outflows to Podemos were C-Equo (34.8\%) and Amaiur (14.6\%).

From the ideological perspective (left-right axis) the votes Podemos received from IU, Amaiur and C-Equo was no surprise, as voters view these parties as ideologically similar. However, one of the features that most surprised analysts was the ability of Podemos to attract voters from the political space of majorities (see Table 1), despite it being seen by this same majority as far removed from them in the left/right axis ${ }^{5}$. The answer challenges the framework: the key to understanding what happened is not completely on the left/right axis. If the interpretive framework from where to understand the Spanish contemporary partisan politics was exclusively on the ideological axis, PP would not have triumphed so widely in the 2011 elections neither would Podemos have got off the ground in 2014. In our view, Podemos growth is because of its ability to highlight the warping of the traditional political orders (left/right; Spanish nationalism/peripheral nationalism) and its willingness to build a new political identity. The

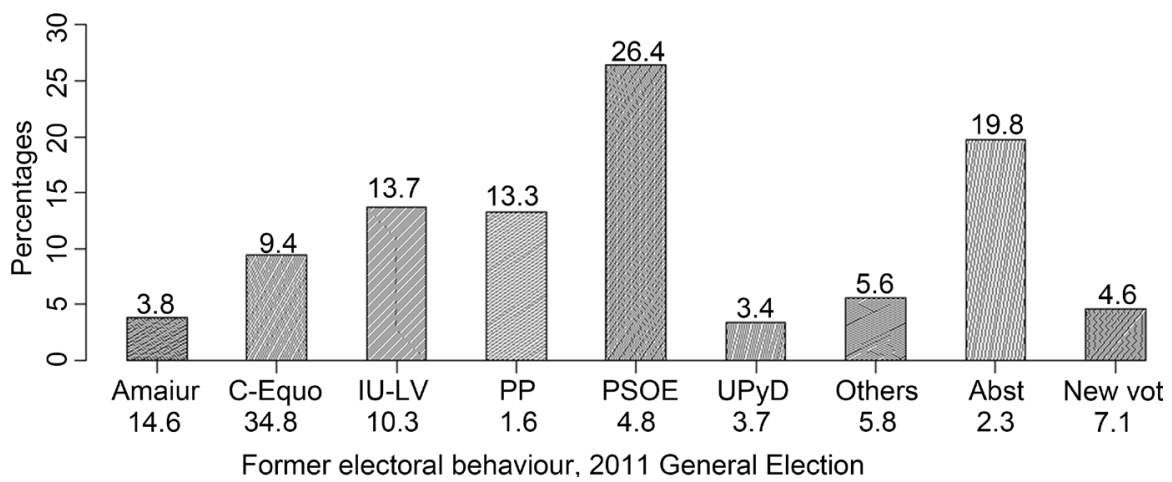

Figure 3. Origin of Podemos votes in 2014 EP election. The numbers under the party labels inform about the percentage of electors of the corresponding option that switched to Podemos. Own elaboration using [37], [40] and 2011 and 2014 actual results [41].

${ }^{5}$ In the space bounded between extreme left (1) and extreme right (10), the May 2014 average position of Spaniards [37] was placed at 4.5. However, electors placed Podemos in 2.5, IU 2.7 and Amaiur 2.1. These same voters stood PSOE at 4.7 and PP in 8.2. 
Table 1. Distribution of voters of main parties in the ideological scale in 2014 EP elections.

\begin{tabular}{ccccccc}
\hline Ideology & Population & PP & PSOE & Podemos & IU & Abstention \\
\hline Extreme left (1 - 2) & 9.5 & 0.3 & 10.2 & 22.8 & 39.4 & 4.8 \\
Left (3 - 4) & 31.7 & 1.0 & 63.2 & 53.3 & 48.2 & 24.4 \\
Centre (5) & 17.4 & 10.1 & 17.2 & 12.7 & 5.8 & 22.4 \\
Right (6 - 7) & 14.9 & 47.4 & 2.5 & 2.5 & 1.5 & 13.3 \\
Extreme Right (8 - 10) & 7.3 & 32.8 & 0.7 & 0.5 & 0.0 & 3.9 \\
Don't know/No answer & 19.2 & 8.4 & 6.3 & 8.1 & 5.1 & 31.1 \\
\hline
\end{tabular}

Source: Own elaboration using self-placement measures given by [37] respondents.

successful delivery of this new identity is based on Podemos aligning themselves to the main issues shared with the majority of voters, adapting a discourse respectful of the hierarchy of the social agenda.

This would explain, as highlighted by posterior polls, the ability of Podemos to attract floating voters of PP and PSOE. A huge group comprising in the 2011 General elections up to $21.9 \%$ of PP voters and $32.9 \%$ of PSOE voters [26]. These voters stated that they placed their ballot with "some doubts" or "with an uncomfortable feeling". This lack of identification of voters with their parties, fed by cleavage changes and the growing concern for particular issues, is increasing the importance of electoral campaigns and blurring party lines. In fact, according to CIS [37], in the 2014 EP election almost $40 \%$ of voters ( $80 \%$ in the case of Podemos) admitted to having decided their vote during the campaign, which is a milestone in Spanish electoral history.

\subsection{Socio-Economic Profile}

From a demographic perspective (Table 2), Podemos first voters were in the majority males, mostly young, being between 18 and 34 years of age, and from an urban background. The proportion of voters with these characteristics was much higher in Podemos that in its competitors. In addition, Podemos voters consider themselves as middle or lower-middle class and appear to have a higher level of education, with almost half its voters having completed university or vocational studies. Podemos attracted a smaller proportion $(9.1 \%)$ of voters with only primary education or no qualifications, which contrasts with PSOE figures. The analysis of the socio-economical profile of these individuals enables us to better understand these results, which point to the generation that has suffered the most as a result of the economic crisis. An important portion of the members of this generation, despite their qualifications, are unable to find some stability on the labour market to move forward with their lives.

In socio-economic terms (Table 3), Podemos stands out as attracting voters with no income but whose family environment was not so different from that of the general population and of its competitors. Indeed, its proportion of family members who were not main breadwinners is significantly higher than that in other parties, being more than $50 \%$ of its voters. This fact, along with the high proportion of young people, 
Table 2. Sociodemographic characteristics of main parties' electorates in 2014 EP elections.

\begin{tabular}{|c|c|c|c|c|c|c|c|}
\hline & & Population & $\mathrm{PP}$ & PSOE & Podemos & IU & Abstention \\
\hline \multirow[t]{2}{*}{ Gender } & Women & 50.8 & 52.3 & 54.0 & 46.7 & 44.5 & 51.2 \\
\hline & Men & 49.2 & 47.7 & 46.0 & 53.3 & 55.5 & 48.8 \\
\hline \multirow[t]{3}{*}{ Age } & 18 to 35 & 26.3 & 13.9 & 13.0 & 35.5 & 26.3 & 32.5 \\
\hline & 35 to 54 & 39.1 & 29.3 & 36.5 & 46.2 & 45.3 & 40.5 \\
\hline & $\geq 55$ & 34.6 & 56.8 & 50.5 & 18.3 & 28.5 & 27.1 \\
\hline \multirow[t]{6}{*}{ Education } & Uneducated & 6.0 & 5.6 & 13.7 & 2.0 & 4.4 & 4.7 \\
\hline & Elementary & 19.3 & 26.5 & 29.1 & 7.1 & 12.4 & 17.6 \\
\hline & Secondary & 25.3 & 21.3 & 24.6 & 23.4 & 16.1 & 28.7 \\
\hline & Baccalaureate & 13.9 & 12.2 & 7.4 & 20.3 & 21.2 & 14.0 \\
\hline & Professional & 16.6 & 10.8 & 11.6 & 20.8 & 21.2 & 18.4 \\
\hline & University & 18.9 & 23.7 & 13.7 & 25.9 & 24.8 & 16.6 \\
\hline \multirow[t]{5}{*}{ Habitat size } & Rural area & 21.8 & 25.9 & 27.3 & 14.5 & 19.4 & 20.9 \\
\hline & Small cities & 26.3 & 22.9 & 26.3 & 23.4 & 25.8 & 27.2 \\
\hline & Medium cities & 12.1 & 11.4 & 11.1 & 13.0 & 11.9 & 12.7 \\
\hline & Big cities & 22.9 & 21.1 & 20.6 & 28.7 & 22.9 & 23.5 \\
\hline & Big capitals & 16.8 & 18.6 & 14.7 & 20.4 & 20.0 & 15.6 \\
\hline Social class & Lower & 7.9 & 3.5 & 10.5 & 3.6 & 4.4 & 9.9 \\
\hline \multirow[t]{4}{*}{ Self-placement } & Lower-middle & 25.0 & 16.7 & 27.0 & 32.5 & 24.8 & 25.4 \\
\hline & Middle & 43.2 & 46.0 & 44.2 & 39.6 & 50.4 & 41.7 \\
\hline & Middle-upper & 19.0 & 26.8 & 12.6 & 22.3 & 16.8 & 18.2 \\
\hline & Upper & 1.4 & 4.5 & 1.1 & 0.5 & 0.7 & 0.9 \\
\hline
\end{tabular}

Source: Own elaboration using CIS [37] and Ministerio del Interior [41].

Table 3. Socioeconomic characteristics of main parties' electorates in 2014 EP elections.

\begin{tabular}{cccccccc}
\hline & & Population & PP & PSOE & Podemos & IU & Abstention \\
\hline Personal & No income & 20.4 & 18.8 & 17.2 & 22.3 & 15.3 & 22.2 \\
Income & $\leq 600 €$ & 15.9 & 8.4 & 25.3 & 13.7 & 14.6 & 16.0 \\
& 601 to $900 €$ & 14.2 & 15.3 & 16.5 & 12.2 & 15.3 & 13.4 \\
& 901 to $1200 €$ & 13.3 & 13.9 & 14.0 & 14.7 & 16.8 & 12.0 \\
& 1201 to $2400 €$ & 13.2 & 17.1 & 10.5 & 13.7 & 19.0 & 11.8 \\
& $\geq 2401 €$ & 1.2 & 1.0 & 2.1 & 0.0 & 0.7 & 1.2 \\
Family & No answer & 21.9 & 25.4 & 14.4 & 23.4 & 18.2 & 23.4 \\
Income & $\leq 900 €$ & 21.9 & 17.8 & 31.9 & 15.7 & 16.8 & 22.1 \\
& 901 to $1,200 €$ & 14.5 & 13.9 & 19.3 & 12.7 & 11.7 & 14.1 \\
& 1201 to $1800 €$ & 15.4 & 16.0 & 12.3 & 18.3 & 27.7 & 13.6 \\
& 1800 to $2400 €$ & 9.1 & 10.8 & 8.4 & 10.7 & 11.7 & 8.1 \\
& $\geq 2401 €$ & 8.1 & 10.8 & 8.4 & 7.1 & 9.5 & 7.2 \\
& No answer & 31.0 & 30.7 & 19.6 & 35.5 & 22.6 & 34.9 \\
Labour & Worker & 39.9 & 33.1 & 28.8 & 49.7 & 46.7 & 42.4 \\
Status & Retired worker & 19.6 & 35.2 & 26.3 & 11.2 & 20.4 & 14.3 \\
& Retired (no worker) & 4.0 & 7.0 & 8.1 & 0.5 & 0.1 & 3.2 \\
& Unemployed & 24.7 & 12.9 & 26.0 & 26.4 & 22.6 & 28.1 \\
& Student & 4.4 & 1.0 & 2.1 & 8.6 & 3.6 & 5.3 \\
& Houseworker & 7.2 & 10.8 & 8.8 & 3.6 & 6.6 & 6.5 \\
& Main & 45.8 & 50.2 & 48.8 & 39.6 & 51.8 & 44.0 \\
Breadwinner & Other & 42.7 & 37.3 & 41.4 & 51.3 & 33.6 & 44.3 \\
& Shared & 10.4 & 11.5 & 8.1 & 7.6 & 13.9 & 10.9 \\
\hline & Sondition & & & & & &
\end{tabular}

Source: Own elaboration using [37]. 
results in a higher level of single people (43.1\%) in its electorate. A figure that contrasts to those of the other main parties: $19.3 \%$ PSOE and $18.5 \%$ PP. This would suggest a greater proportion of Podemos voters still living at parents' home, because of low salaries or the lack of employment, or because they are still studying. In contrast, the proportion of pensioners voting for Podemos was less than half the level of the other parties.

In short, in socio-demographical and socio-economical terms, the profile of Podemos first voters could be described as young, with leftist ideology and socially ascending, with a higher level of education and strong commitment to the new middle classes. Podemos was not only working class but also a group that encompasses an electorate half-way between IU and PSOE profiles. These are not the only interesting issues that can be derived from this survey. Further analysis of microdata [37] also reveals (numbers not shown here) that EP Podemos electors view themselves as having a greater political awareness compared to "most people". Broadly speaking, Podemos voters have a more proactive attitude towards politics and belong to politically active (online) networks; with larger proportions of its supporters following political developments on mass media, social networks and digital media. Their level of disenchantment with the current political scene, however, is in line with voters from other parties; with the exception of PP voters, who are slightly less sceptical about politicians and politics. The EP post-survey also offer insights to assessing Podemos media communicative strategy pointed out in section 4. Despite TV channel La Sexta only sharing 7.2\% of Spanish TV audience in 2014, the great majority of Podemos voters (35\%) chose this station to be informed about politics. Cuatro also appears as a popular option, especially compared with electorates of the other parties.

The data ultimately endorses two hypotheses of Podemos electoral strategy. Firstly, the increased permeability of the electorate to social situations in a critical moment of strong distrust of institutions and traditional forces, with the consequent weakening of traditional left/right (and nationalists) patterns. Secondly, the influence that Iglesias' profile as the party image had on the results. His presence on TV (La Sexta and Cuatro), coupled with a successful campaign through social networks and the Internet, achieved high visibility for Podemos and its message, despite the greater weight of the traditional parties in the media and the limited resources of Podemos.

\section{Conclusions}

In the European elections of May 2014, something unprecedented in Spanish politics occurred. A new, unknown group, created just four months earlier and without apparent financial resources, became the fourth political party of the country, triggering a political earthquake. What's more, according to polls, it was only a year later in a position to challenge in the next general election the supremacy of the two traditional major parties, PP and PSOE. Something confirmed two years later in the December, 2015 General election.

In this paper, we analyse the conditions that made this fact possible and the strategy 
followed by Podemos to harness the benefits that the economic, political and institutional crises offered to empower the emergence of a new political presence in Spain. The innovative change of cleavages proposed by Podemos and the great exposure of its leader to mass media has enabled them to transmit to the people its new and fresh discourse, based on a new dichotomous division of society: the people against the (corrupted) elites.

Podemos is picking off the less-identified voters of both PP and PSOE, and mobilizing important areas of previous abstainers as well as gobbling up small parties. Compared to voters of major parties, Podemos supporters are younger, more urban and educated, and consequently they use digital social networks to a greater degree. Its support comes mainly from people located in the (extreme) left of the ideological spectrum and among those who see themselves as being lower-middle or middle class, those who are currently unemployed or those who are working but receiving a low salary, being mainly no family breadwinners. The analyses of CIS polls also support the main hypotheses of Podemos electoral strategy: the growing weakness of ideological identification of Spanish voters and their increased permeability to particular issues, and the election of Pablo Iglesias as party image given his increased exposure on TV (La Sexta and Cuatro).

\section{Acknowledgements}

The authors wish to thank Marie Hodkinson for her help translating the paper into English and a reviewer for its valuable comments. This work was supported by the Spanish Ministry of Economics and Competitiveness under grant CSO2013-43054-R.

\section{References}

[1] Galais, C. (2014) Don't Vote for Them: The Effects of the Spanish Indignant Movement on Attitudes about Voting. Journal of Elections, Public Opinion and Parties, 24, 334-350. http://dx.doi.org/10.1080/17457289.2014.887089

[2] CIS (2014) Estudio 3028. Barómetro Octubre 2014. http://goo.gl/kiJ7f9

[3] Stavrakakis, Y. and Katsambekis, G. (2014) Left-Wing Populism in the European Periphery: The Case of SYRIZA. Journal of Political Ideologies, 19, 119-142. http://dx.doi.org/10.1080/13569317.2014.909266

[4] CIS (1998) Estudio 2286. Instituciones y Autonomías (I). http://goo.gl/KrWWhx

[5] CIS (1998) Estudio 2309. Constitución e Instituciones (III), 20 Aniversario de la Constitución. http://goo.gl/HEE3Gw

[6] CIS (1998) Estudio 2311. Barómetro Noviembre 1998. http://goo.gl/gx2s2E

[7] CIS (2012) Estudio 2956. Barómetro Autonómico (III). http://goo.gl/IYQOXY

[8] CIS (2012) Estudio 2966. Barómetro Noviembre 2012. http://goo.gl/c0BYX2

[9] CIS (2013) Estudio 3005. Barómetro Noviembre 2013. http://goo.gl/ZHMYIL

[10] Reher, S. (2015) Explaining Cross-National Variation in the Relationship between Priority Congruence and Satisfaction with Democracy. European Journal of Political Research, 54, 160-181. http://dx.doi.org/10.1111/1475-6765.12077

[11] CIS (2014) Estudio 3011. Barómetro Enero 2014. http://goo.gl/f2AWPd 
[12] Toharia, J.J. (2014) Las señales estaban ahí. El País, 26 May 2014. http://goo.gl/4zd2JJ

[13] Subirats, J. (2014) De herederos, sucesores y advenedizos. El País, 7 September 2014. http://goo.gl/7lFfZL

[14] Iglesias, P. (2014) Disputar la Democracia. Política para Tiempo de Crisis. Akal, Madrid.

[15] Errejón, I. (2011) EVO Pueblo. La hegemonía del MAS. In: Errejón, I. and Serrano, A., Eds., Ahora es cuándo, carajo! Del Asalto a la Transformación del Estado en Bolivia,. El Viejo Topo, 111-141.

[16] Gibson-Graham, J.K. (2000) Poststructural Interventions. In: Sheppard, E. and Barnes, T., Eds., A Companion to Economic Geography, Blackwell, Oxford, 95-110.

[17] Peet, R. (1998) Modern Geographical Thought. Wiley, Hoboken.

[18] Laclau, E. and Mouffe, C. (1985) Hegemony and Socialist Strategy: Towards a Radical Democratic Politics. Verso, London.

[19] Laclau, E. (2005) On Populist Reason. Verso, London.

[20] Laclau, E. (2005) La izquierda ya no está aislada. Interview to Ernesto Laclau by Keve, C. in Página12. http://goo.gl/BuA8gR

[21] Iglesias, P. (2005) Un nuevo poder en las calles. Repertorios de acción colectiva del Movimiento global en Europa. De Seattle a Madrid. Política y Sociedad, 42, 63-93.

[22] Juliá, S. (2014) Gente será, más gente empoderada. El País, August, 8, 2014. http://goo.gl/190UWd

[23] Podemos (2014) Borrador de Ponencia Política. http://goo.gl/PBkUaS

[24] Errejón, I. (2014) PODEMOS como práctica cultural emergente frente al imaginario neoliberal: hegemonía y disidencia. Conversación con Iñigo Errejón Galván. Revista Científica de Información y Comunicación, 11, 17-46.

[25] CIS (1996) Estudio 2210. Postelectoral Elecciones Generales 1996. http://goo.gl/uQGGte

[26] CIS (2012) Estudio 2920. Postelectoral Elecciones Generales 2011. Panel (2a Fase). http://goo.gl/Qiuau1

[27] Ignatieff, M. (2013) Fire and Ashes: Success and Failure in Politics. Harvard University Press, Harvard. http://dx.doi.org/10.4159/harvard.9780674729650

[28] Luque Sánchez, P. (2014) Puntos fuertes y débiles en política. El País, 26 July 2014. http://goo.gl/d75da1

[29] Cogburn, D.L. and Espinoza-Vasquez, F. (2011) From Networked Nominee to Networked Nation: Examining the Impact of Web 2.0 and Social Media on Political Participation and Civic Engagement in the 2008 Obama Campaign. Journal of Political Marketing, 10, 189213. http://dx.doi.org/10.1080/15377857.2011.540224

[30] Flesh Fominaya, C. (2011) The Madrid Bombings and Popular Protest: Misinformation, Counter-Information, Mobilisation and Elections after "11-M". Contemporary Social Science: Journal of the Academy of Social Sciences, 6, 289-307. http://dx.doi.org/10.1080/21582041.2011.603910

[31] Gómez, L. and Viejo, M. (2014) Las redes de arrastre de Podemos. El País, 30 May 2014. http://goo.gl/j9ndqi

[32] El País (2014) Las redes de arrastre de Podemos. El País, 15 November 2014. http://goo.gl/vDaVox

[33] Errejón, I. (2013) Sin manual, pero con pistas: algunas trazas comunes en los procesos constituyentes andinos (Venezuela, Bolivia, Ecuador). Viento Sur, 128, 27-37.

[34] Pavía, J.M. and Larraz, B. (2012) Nonresponse Bias and Superpopulation Models in Elec- 
toral Polls. Reis, 137, 237-264. http://dx.doi.org/10.5477/cis/reis.137.237

[35] Groves, R.M., Dillman, D.A., Eltinge, J.L. and Little, R.J.A. (2002) Survey Nonresponse. Wiley, New York.

[36] Noelle-Neumman, E. (1993) The Spiral of Silence: Public Opinion-Our Social Skin. The University of Chicago Press, London.

[37] CIS (2014) Estudio 3028. Post-Electoral al Parlamento Europeo 2014. http://goo.gl/kiJ7f9

[38] CIS (2004) Estudio 2559. Postelectoral Elecciones Generales y Autonómicas de Andalucía 2004. http://goo.gl/p1EY2F

[39] Bali, V. (2007) Terror and Elections: Lessons from Spain. Electoral Studies, 26, 669-687. http://dx.doi.org/10.1016/j.electstud.2007.04.004

[40] INE (2014) Datos Relativos a Elecciones al Parlamento Europeo 2014. http://goo.gl/FrD32X

[41] Ministerio del Interior (2014) Resultados Electorales Elecciones al Parlamento Europeo 2014. http://www.infoelectoral.interior.es/min/

[42] Pavía J.M., Cabrer B. and Sala R. (2009) Updating Input-Output Matrices: Assessing Alternatives through Simulation. Journal of Statistical Computation and Simulation, 79, $1467-$ 1498. http://dx.doi.org/10.1080/00949650802415154 


\section{Supplementary Material}

Table S1. Estimate of vote transfer matrix between 2011 General election and 2014 EP Election.

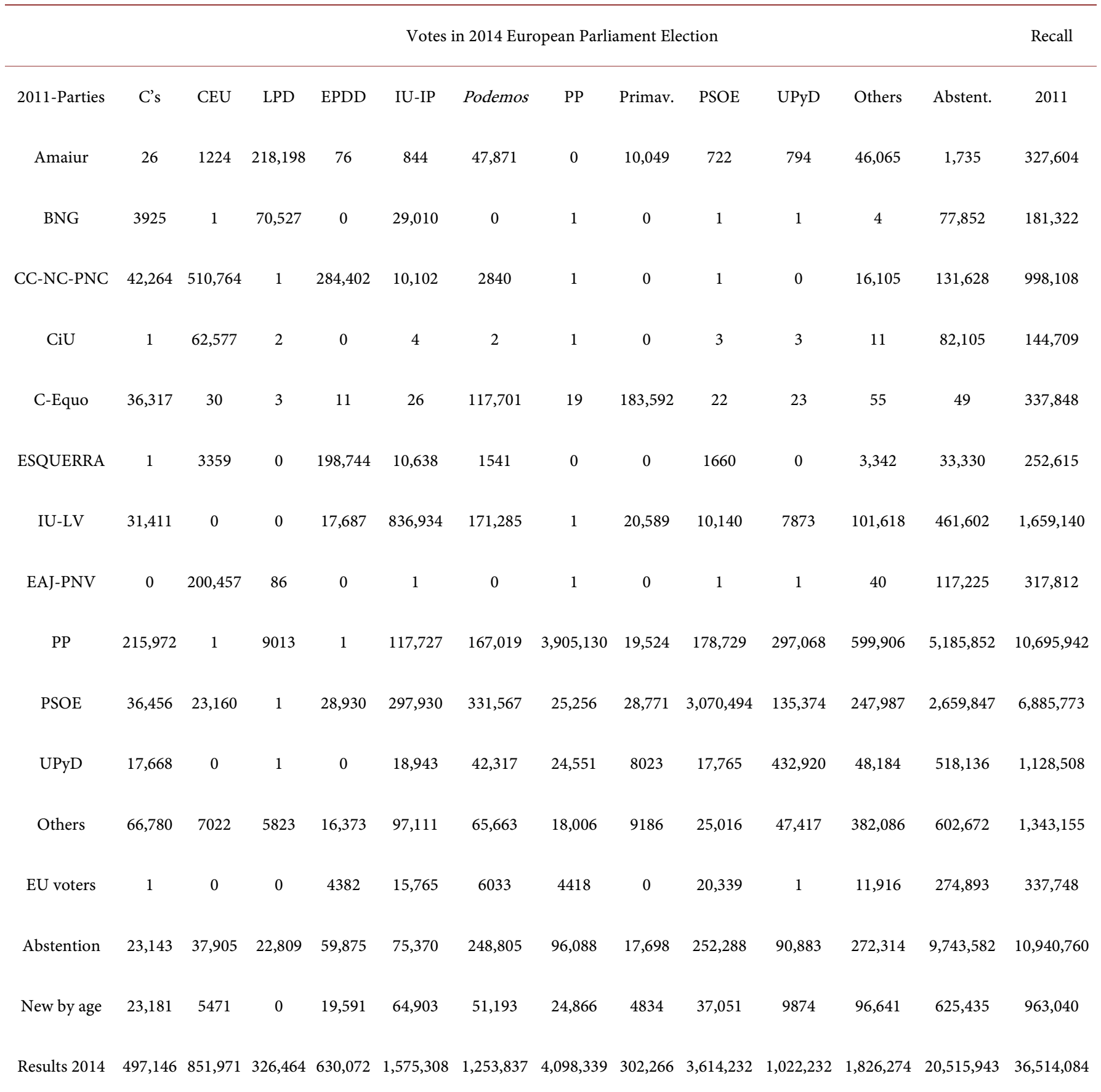

Source: Own elaboration using 2011 and 2014 actual results [41], [37] and[40]. The final matrix has been obtained after balancing, using the RAS procedure [42], the initial raw vote transfer matrix estimated from the EP election post-electoral survey [27]. Others include null and blank votes. 
Submit or recommend next manuscript to SCIRP and we will provide best service for you:

Accepting pre-submission inquiries through Email, Facebook, LinkedIn, Twitter, etc. A wide selection of journals (inclusive of 9 subjects, more than 200 journals)

Providing 24-hour high-quality service

User-friendly online submission system

Fair and swift peer-review system

Efficient typesetting and proofreading procedure

Display of the result of downloads and visits, as well as the number of cited articles

Maximum dissemination of your research work

Submit your manuscript at: http://papersubmission.scirp.org/

Or contact jss@scirp.org 